\title{
Safe Method for the Treatment of Primary Hyperparathyroidism in Geriatric Patients: Minimally Invasive Parathyroidectomy
}

\author{
Geriatrik Hastalarda Primer Hiperparatiroidi Tedavisinde Güvenli Yöntem: Minimal Invazif Paratiroidektomi
}

\author{
Mehmet Fatih Ekici', Fatih Kuzu², Sezgin Zeren', Ali Cihat Yildirim', Erhan Akdemir³ , Faik Yaylak', \\ Kevser Onbasi ${ }^{4}$, Mustafa Cem Algin ${ }^{1}$
}

${ }^{1}$ General Surgery Department, Kutahya Health Sciences University Faculty of Medicine, Kutahya; ${ }^{2}$ Department of Internal Medicine, Endocrinology Metabolism Department, Istinye University Faculty of Medicine, Istanbul; ${ }^{3}$ Department of Nuclear Medicine, ${ }^{4}$ Department of Internal Medicine, Endocrinology Metabolism Department, Kutahya University of Health Sciences, Faculty of Medicine, Kutahya, Turkey

\begin{abstract}
Aim: Primary hyperparathyroidism is the most important cause of clinically hypercalcemia. Parathyroid adenomas are the most common endocrinology disorder in primary hyperparathyroidism. In this study, we aimed to evaluate the reliability of this surgery in patients older than 65 years by examining the data of patients who underwent parathyroidectomy for parathyroid adenoma.
\end{abstract}

Material and Method: Patients were divided into two groups as those aged 65 years and over and adults. Age, gender, comorbidities, ASA score, preoperative and postoperative laboratory findings, imaging methods and operative times were reviewed. A $p$ value of $<0.05$ was used for significance.

Results: Ninety patients with parathyroid adenoma were included in the study. Female gender was dominant in both groups. The mean age was 52.15 3 8.87 in Group 1 and 71.39 3 5.76 in Group 2. When the associated co-morbidity was evaluated, no statistical difference was found between the two groups for diabetes mellitus and hypertension diseases. When the patients with nephrolithisis were evaluated, there were 21/64 (32\%) kidney stones in group 1 and 6/26 (23\%) kidney stones in group 2 and there was no statistical difference in both groups. Although the ASA score was higher in the geriatric group, there was no difference between the duration of surgery and length of hospital stay. There were no postoperative complications and morbidity.

Conclusion: Adenoma surgery is an effective treatment method for primary hyperparathyroidism. Additional diseases and geriatric age period patients do not lead to an increase in surgical efficacy and complication rates. The surgeon procedure time was not prolonged despite the significant difference in ASA score in geriatric patients. Minimally invasive parathyroidectomy is a safe surgical procedure in geriatric patients. Our study as far as we know is the first in our literature about minimal invasive parathyroidectomy on geriatric patients.

Key words: minimally invasive parathyroidectomy; geriatric patient; primary hyperparathyroidism surgery

\section{ÖZET}

Amaç: Primer hiperparatiroidi klinik olarak saptanan hiperkalseminin en onemli sebebidir. Paratiroid adenomlar primer hiperparatiroidi tablosunda en sık rastalanan endokrinoloji bozukluktur. Bu calıșmada paratirod adenom nedeni ile paratiroidektomi yapılan hastaların verileri incelenerek minimal invazif paratiroid cerrahisinin 65 yaș uzeri hastalarda guvenirliğinin değerlendirilmesi amaclandı.

Materyal ve Metot: Hastalar 65 yaș uzeri olanlar ve erișkin yaș grubu olarak iki gruba ayrıldı. Yaș, cinsiyet, ek hastalıklar ASA skoru, preoperatif ve postoperatif labaratuar bulguları, görüntüleme yöntemleri ve ameliyat süreleri gözden geçirildi. $p$ değerinin anlamlı̆ğı için <0,05 değeri kullanıldı.

Bulgular: Paratiroid adenomlu 90 hasta çalıșmaya dahil edildi. Her iki grupta kadın cinsiyeti baskındı. Grup 1'de yaș ortalaması

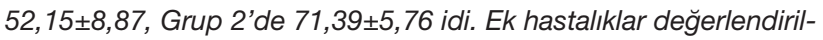
diğinde, diabetes mellitus ve hipertansiyon hastalıkları açısından iki grup arasında istatistiksel fark bulunmadı. Nefrolityasizi olan hastalar değerlendirildiğinde grup 1'de 21/64 (\%32) böbrek tașı ve grup 2'de 6/26 (\%23) böbrek tașı vardı ve her iki grupta da istatistiksel fark yoktu. Geriatrik grupta ASA skoru daha yüksek olmasına rağmen ameliyat süresi ve hastanede kalıș süreleri arasında fark yoktu. Ameliyat sonrası komplikasyon ve morbidite yoktu.

Sonuç: Adenom cerrahisi primer hiperparatiroidizm tedavisinde etkili tedavi metodudur. Ek hastalıklar ve geriatrik yaș grubu hastalar; cerrahinin etkinliğinde ve komplikasyon oranlarında artıșa sebep olmamaktadır. Cerrahi ișlem süresi geriatrik hasta grubunda ASA skorundaki anlamlı farklıı̆ga rağmen uzamamıștır. Minimal invazif paratiroidektomi geriatrik hasta grubunda güvenle uygulanabilecek cerrahi yöntemdir. Çalıșmamı literatürde ülkemizden geriatrik hastalarda minimal invaziv paratiroidektomi ile ilgili bildiğimiz ilk çalıșmadır.

Anahtar kelimeler: minimal invaziv paratiroidektomi; geriatrík hasta; primer hiperparatiroidizm cerrahisi

Iletișim/Contact: Mehmet Fatih Ekici, Kutahya Health Sciences University Faculty of Medicine, General Surgery Department, Kutahya, Turkey • Tel:05326016904 • E-mail:mfatihekici@gmail.com • Gelis/Received: 03.01.2020 • Kabul/Accepted: 15.05.2020

ORCID: Mehmet Fatih Ekici, 0000-0002-1247-1139 • Fatih Kuzu, 0000-0002-7301-9226 • Sezgin Zeren, 0000-0002-9342-1706 • Ali Cihat Yuldirtm, 0000-0001-5379-2804 • Erhan Akdemir, 0000-0001-9181-9051 • Faik Yaylak, 0000-0002-1216-0429 • Kevser Onbaşı, 0000-0003-2230-9263 • Mustafa Cem Algın, 0000-0003-2152-878X 


\section{Introduction}

The expected human life expectancy has increased due to developing technology including new treatment opportunities and screening modalities ${ }^{1}$. Therefore, with the increasing elderly population, the number of elderly patients undergoing surgery are increasing day to day. The patients over 65 years old are named as geriatric patients ${ }^{2}$.

Elderly patients in need of surgery represent a significant proportion of the general surgical population. Information collected from the American National Institute of Health (NIH) Survey reported that, 65 years and older patients accounted for $35.3 \%$ of all inpatient procedures and $32.2 \%$ of all outpatient procedures. Although the mortality risk is higher, there is a relative lack of scientific literature examining perioperative health care models in elderly patients $(\geq 75 \text { years })^{1,2}$.

In the geriatric patients, endocrine disorders occur with atypical, nonspecific symptoms and are often not recognized earlier. The incidence of endocrine diseases, particularly diabetes mellitus (DM), hypothyroidism and hyperparathyroidism, increases with age; the latter two are more common in women ${ }^{2}$.

Primary hyperparathyroidism (PHP) is the third most common endocrine disease among all endocrine diseases. $10 \%$ of cases are part of autosomal dominant hereditary diseases ${ }^{3}$.

PHP is the most important and common cause of hypercalcemia in geriatric patients ${ }^{4}$. The incidence increased from 10 in 100,000 people under the age of 40 , to 40 in 100,000 among those up to the age of $65^{5}$.

The aim of this study is to determine the differences between geriatric patients and age under 65 years patients undergoing minimal invasive parathyroid surgery for PHP.

\section{Material and Method}

A retrospective study is designed to evaluate the outcomes after parathyroid surgery in geriatric patients. The study protocol was approved by the hospital administration. Informed constent was obtained from all patients and personal identification information of patients are not shared this study.

Demographic, clinical and laboratory datas of patients who underwent parathyroid surgery for PHP between January 2014 and June 2019 at Kutahya

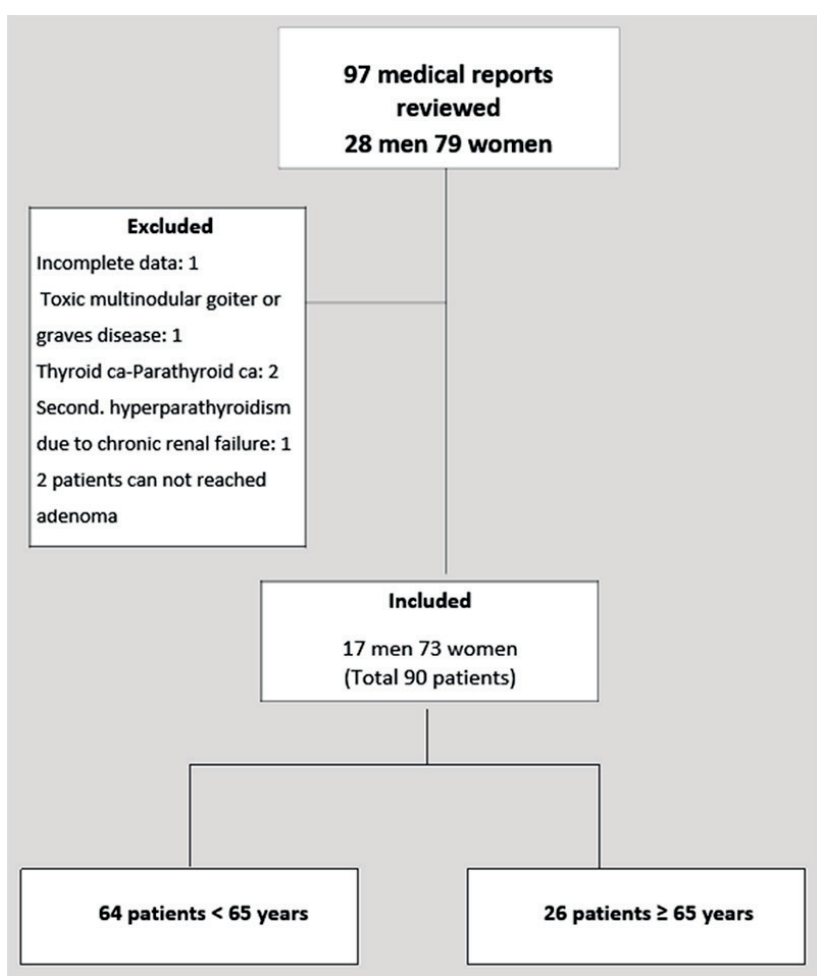

Figure 1. Group design in the study.

Health Sciences University Evliya Celebi Training and Research Hospital were retrospectively analyzed. 90 patients were included in the study. Patients with secondary hyperparathyroidism due to chronic renal failure, patients with toxic multinodular goiter or graves disease, incomplete data were excluded (7 patients). Two groups were designed to assess the role of age on parathyroid adenoma surgery. Patients were divided into two groups due to their age. First group patients were $<65$ years and second group is geriatric group whose age were $\geq 65$ years (Figure 1). Demographic parameters and their relations, with imaging and laboratory findings were compared between study groups (Table 1). Age, gender and releated diseases (dibates mellitus, hypertension) were recorded for analysis. Body mass index were excluded from the analysis due to incomplete records or inappropriate measurements. All related demographic and clinical information was retrieved and analyzed.

All patients were referred from an experienced endocrinologist. Preoperative blood tests, ultrasonography, 90 mTc-MIBI scintigraphy and washout examination were observed routinely before surgery. All of the patients who underwent surgery had single parathyroid adenoma. Parathyroid adenomas were 
Table 1. Variables of the study

\begin{tabular}{lccc}
\hline Variables & $<65$ years n: 64 & $>65$ years n: 26 & $\mathrm{p}$ value \\
\hline Sex (F/M) & $54 / 10$ & $19 / 7$ & 0,001 \\
Age & & & \\
$\quad$ years (mean \pm SD) & $52,15 \pm 8,87$ & $71,39 \pm 5,76$ & 0,0412 \\
Diabetes Mellitus & $18 / 64 \% 28,12$ & $13 / 26 \% 50$ & 0,062 \\
Hypertension & $25 / 64 \% 39$ & $7 / 26 \% 26,9$ & 0,076 \\
Nephrolithiasis & $21 / 64 \% 32$ & $6 / 26 \% 23$ & 0,089 \\
90 mTC-MIBI & $52 / 64 \% 81$ & $20 / 26 \% 76,9$ & 0,072 \\
$\quad$ scintigraphy & & & \\
USG & $61 / 64 \% 95$ & $24 / 26 \% 92$ & 0,083 \\
Washout examination & $53 / 64 \% 83$ & $21 / 26 \% 81$ & 0,065 \\
ASA Score & $1-0,5(1-2)$ & $2-1(2-3)$ & 0,000 \\
Operative time & $75-20(45-120)$ & $75-28,75(50-120)$ & 0,074 \\
Length of hospital stay & $1-3(1,2)$ & $1-4(1,4)$ & 0,064 \\
\hline
\end{tabular}

verified via gamma-probe and removed by dissection to the unilateral marked area in accordance with the principles of minimally invasive surgery. Vessel and tissue sealer ultrasonic dissector were used as an energy device in all operations. Postoperative bleeding status, nerve injury, seroma and wound infection datas were obtained from all patients' medical records. Sucker drainage tube (hemovac) was placed at the operation site and removed at postoperative first 24th hour. Preoperative and postoperative calcium levels were calculated as corrected calcium levels with albumin levels. Surgical intervention failed in two patients. A 84-year-old female patient had an adenoma in the mediastinum; adenoma was not detected in the mediastinal exploration with sternotomy. A 72-yearold male patient with adenoma was not detected although all surgical thyroid lobes were evaluated. In these patients, PTH and calcium levels remained elevated during follow-up. One year later, the patient (72-year-old male) reevaluated with neck and thorax $\mathrm{CT}$, adenoma was detected under the clavicle on the left side, the patient was reoperated and the adenoma under the left clavicle was excised.

In the postoperative period, biochemical hypocalcemia was defined as a total calcium level below $8.5 \mathrm{mg} / \mathrm{dL}$ and the level above $11 \mathrm{mg} / \mathrm{dL}$ was hypercalcemia. ${ }^{25} \mathrm{OHD}$, parathormone and thyroid stimulating hormone (TSH) chemilumination levels were determined by immunoassay measurement method (Beckman Coulter DXI-800, Beckman Coulter, Inc. Fullerton, CA 92835 USA). Alkaline phosphatase
(ALP), calcium, phosphorus levels were measured by Beckman Coulter AU 2700, Beckman Coulter, Inc., Brea, CA 92821 USA. The complete blood counts were determined with laserbased impedance using an automated blood cell counter (Mindray BC-6800, Nanshan, Shenzhen, PR China).

The statistical analysis of the data was performed using the "SPSS 18.0 (IBM statistics for Window version 18, IBM Corporotion Newyork, USA). All data were summarized by supporting tables and graphs. During the evaluation, descriptive statistical methods (mean, standard deviation, median, interquartile range, minimum and maximum value) were used. T test was used in the same sample group of the quantitative data in the appropriate distribution of adult and geriatric groups in the appropriate distribution. Datas in groups not showing the appropriate distribution Wilcoxon Signed Rank test was used. The results were statistically with a confidence interval of $95 \%$. Besides, the results of $p$ value $<0.05$ were accepted as significant.

\section{Results}

The demographic and clinical profiles of patients in group 1 and group 2 were presented in Table 1. There were 54 female, 10 male patients in group 1 and $19 \mathrm{fe-}$ male and 7 male patients in group $2(p>0.001)$. Mean age was 52 years (26-64) in group 1 and 71 years in group $2(p=0.0412)$. (Table 1$)$ There is no significant difference between groups including sex. There is a meaningful difference due to age between study groups.

When chronic diseases were evaluated; diabetes mellitus was present in 18 patients $(28 \%)$ in group 1 and 13 patients $(50 \%)$ in group $2(\mathrm{p}=0.062)$. Hypertension was present in 25 patients $(38 \%)$ in group 1 and 7 patients $(26.9 \%)$ in group $2(p=0.076)$. In the preoperative period, nephrolithiasis was detected in 21 patients $(32 \%)$ in group 1 and in 6 patients $(23 \%)$ in group $2(\mathrm{p}=0.089)$. ASA score was significantly higher in group $2(\mathrm{p}<0.001)$. (Table 1$)$

In group 1, USG was 95\% successful in detecting adenomas $(61 / 64)$, and $92 \%$ in group $2(20 / 26)(p=0.083)$. Ultrasound guided wash out was performed in all patients; 11 patients in group 1 were negative with wash out, in geriatric patients, 5 were negative. In $90 \mathrm{mTc}$ MIBI scintigraphy, 52 patients $(81 \%)$ in group 1 and 20 patients $(76.9 \%)$ in group 2 had positive results $(\mathrm{p}=0.072)$. (Table 1$)$ 
Preopearative corrected mean total calcium levels in group $1 ; 11.7(10.1-14.2) \mathrm{mg} / \mathrm{dl}$ and $11.6(10-13.3)$ $\mathrm{mg} / \mathrm{dl}$ in group $2(\mathrm{p}=0.0612)$. Postoperative 10th minute mean total calcium measurement levels in groupl was $8.78(7.8-10.1) \mathrm{mg} / \mathrm{dl}$ and 8.6 (7.9-9.8) $\mathrm{mg} / \mathrm{dl}$ in group $2(\mathrm{p}=0.380)$. Postoperative 1 st Day mean corrected total calcium levels in group 1 was $9(8.30-10.5) \mathrm{mg} / \mathrm{dl}$ and $8.9(7.9-9.8) \mathrm{mg} / \mathrm{dl}$ in group $2(\mathrm{p}<0.001)$. Postoperative 1 st Month mean corrected total calcium levels in group 1 was 9.53 $(8.75-10.3) \mathrm{mg} / \mathrm{dl}$ and $9.54(9-10.4) \mathrm{mg} / \mathrm{dl}$ in group $2(\mathrm{p}=0.100)$. (Table 2$)$

Preopearative mean PTH levels in group 1 were 202 (77-910) pg/dl, $229(111-690) \mathrm{pg} / \mathrm{dl}$ in group 2 $(\mathrm{p}=0.0761)$. Postoperative 10. minute mean PTH levels in group 1 were $20(0.01-200) \mathrm{mg} / \mathrm{dl}, 5$ (329) $\mathrm{pg} / \mathrm{dl}$ in group $2(\mathrm{p}<0.001)$. Postoperative 1 st Month control mean PTH levels were in group $54(10-190) \mathrm{pg} / \mathrm{dl}, 49(10-90) \mathrm{pg} / \mathrm{dl}$ in group 2 $(\mathrm{p}=0.010)$ (Table 2).

When the operation time between the two groups was evaluated; there was no significant difference between geriatric and adult groups.

\section{Discussion}

Parathormone is the most important regulator of calcium level. Hypercalcemia, hypophosphatemia and severe osteoporosis may present with excessive secretion of parathormone. Besides, hyperparathyroidism is one of the leading endocrine diseases. It's classified as primary, secondary and tertiary in 3 groups. The most common parathyroid disease is PHP. PHP is also seen in multiple endocrine neoplasia (MEN) syndrome type I and rarely in IIA $^{6}$. All patients included in our study had PHP and no MEN syndrome was detected.

The causes of PHP are parathyroid adenomas (8090\%), parathyroid hyperplasia (10-20\%) and parathyroid malignancy $(1 \%)^{7}$. The rate of ectopic localization among all parathyroid adenomas is $15-20 \%{ }^{8}$. $5 \%$ of these ectopic adenomas are localized in the mediastinum, and these ectopic adenomas are usually located in the thymus?. In our study, surgery was unsuccessful in 2 patients, the first one had a mediastinal parathyroid adenoma in a 84-year-old woman and the other patient had adenoma in the subclavian area. Second patient's adenoma was removed at reoperation 1 year after the

Table 2. Biochemical variables of the study

\begin{tabular}{|c|c|c|c|}
\hline Variables & $<65$ years $n: 64$ & $>65$ years $n: 26$ & $p$ value \\
\hline TSH. ulU/mL (mean \pm SD) & $1,98 \pm 1,24$ & $1,75 \pm 1,09$ & 0,104 \\
\hline Free T4. ng/dl (mean \pm SD) & $0,90 \pm 0,22$ & $0,89 \pm 0,12$ & 0,126 \\
\hline WBC. $10^{3} / \mathrm{mm}^{3}($ mean $\pm \mathrm{SD})$ & $7,8 \pm 2,76$ & $7,19 \pm 1,44$ & 0,473 \\
\hline Hemoglobine. g/dl (mean \pm SD) & $13,28 \pm 1,61$ & $12,96 \pm 2,02$ & 0,502 \\
\hline Hematocrit. \% (mean \pm SD) & $40,486 \pm 4,35$ & $39,693 \pm 5,76$ & 0,413 \\
\hline Platelet. $10^{3} / \mathrm{mm}^{3}$ (mean $\left.\pm \mathrm{SD}\right)$ & $273,4 \pm 78,17$ & $230,78 \pm 62,13$ & 0,937 \\
\hline 25- Hidroksivitamine D (preop). ng/ml [median- IQR (min-max)] & $10,9-16(4-76)$ & $18,8-16(4-71)$ & 0,000 \\
\hline Preoperative $\mathrm{Ca}^{+2} . \mathrm{mg} / \mathrm{dl}($ mean $\pm \mathrm{SD})$ & $11,7 \pm 0,9$ & $11,6 \pm 1,22$ & 0,0612 \\
\hline Postoperative $\mathrm{Ca}^{+2} .10$. Minute $\mathrm{mg} / \mathrm{dl}$ (mean \pm SD) & $8,78 \pm 0,96$ & $8,66 \pm 1,09$ & 0,380 \\
\hline Postoperative $\mathrm{Ca}+{ }^{2} 1$ st day. mg/dl (mean $\pm \mathrm{SD}$ ) & $9 \pm 1,45$ & $8,9 \pm 0,94$ & 0,000 \\
\hline Postoperative $\mathrm{Ca}^{+2} 1$ st month. $\mathrm{mg} / \mathrm{dl}$ (mean $\pm \mathrm{SD}$ ) & $9,53 \pm 0,87$ & $9,54 \pm 0,54$ & 0,100 \\
\hline Preoperative phosphorus. mg/dl (mean \pm SD) & $2,35 \pm 0,62$ & $2,32 \pm 0,54$ & 0,049 \\
\hline Postoperative phosphorus 1 st month. mg/dl (mean \pm SD) & $3,27 \pm 0,64$ & $3,49 \pm 0,60$ & 0,481 \\
\hline Parathormone preoperative pg/ml [median- IQR (min-max)] & $202-228,5(77-910)$ & $229-326(111-690)$ & 0,0761 \\
\hline Parathormone postoperative 10th Minute pg/ml [median- IQR (min-max)] & $20-14(0,10-200)$ & $5-8,5(0,01-29)$ & 0,001 \\
\hline Parathormone postoperative 1 st month pg/ml [median- IQR (min-max)] & $54-49(0,01-309)$ & 49-48 (10-90) & 0,010 \\
\hline Alkaline phosphatase preoperative. U/L [median- IQR (min-max)] & 104-78 (37-728) & $113-49(43-139)$ & 0,400 \\
\hline Alkaline phosphatase postoperative. U/L [median- IQR (min-max)] & $93-65(32-261)$ & $85-51,25(43-139)$ & 0,920 \\
\hline
\end{tabular}


first surgery. Our unsuccessful intervention rate is lower than 3\% in PHP surgery and this correlated with literature ${ }^{8,9}$.

PHP is seen in nearly $3 \%$ of postmenopausal women and $2 \%$ in elderly population. Parathyroidectomy provides curative treatment in $95 \%$ of patients with PHP. There is a consensus indicating that all PHP patients under the age of 50 should be treated with or without symptoms. There are also studies on the safety of parathyroidectomy in patients over 75 years of age ${ }^{4}$. In our study, the mean age was 71 in geriatric group and the age range was $65-90$ years. Safe minimally invasive parathyroidectomy was performed in our all patients.

In PHP patients, high levels of hypercalcemia and low to normal levels of phosphorus are detected. In patients with moderate to mild hyperparathyroidism, calcium levels may be normal in some measurements. In the elderly patient group, serum calcium levels should be calculated considering albumin level. In the elderly patient group, despite high calcium levels, suppressed PTH levels should suggest malignant diseases ${ }^{10}$.

Hyperparathyroidism in the elderly patient population may present with different symptoms and signs than the young and middle aged patients. The clinical picture is generally includes fatigue, reduced intellectual capacity, emotional instability, loss of appetite and constipation and nephrolithiasis. Postmortem autopsy studies show a high rate of parathyroid adenoma in the geriatric group. Female gender is dominant. In our study, the female patient group was dominant in both groups. Kidney Stones develop in 10-25\% of patients ${ }^{11}$. In our study nephrolithiasis was present in $23 \%$ of elderly patients and there was no statistical difference between groups.

Geriatric patients are affected by the common burden of metabolic and cardiovascular comorbid diseases. However, the use of new surgical and anesthesia techniques reduces the duration of surgery and the incidence of some complications ${ }^{12}$.

Operative risk increases due to co-morbid diseases in elderly patients with hyperparathyroidism. In geriatric group our patients American Society of Anesthesiologists Score (ASA) were higher because of this. Surgical success rate has increased with shorter operation time and less complicated surgical models with minimally invasive approach targeting the location of adenoma ${ }^{13}$. In all patients multidisciplinary approach was preferred. In all patients; washout examination,
USG and 90 mTc-MIBI scintigraphy scans were performed routinely. There is no statistical difference between our groups for successfull adenoma localisation. Frozen section pathologic evaluation was not preferred for any cases during surgery. Washout examination increases the localisation of suspected adenomas rate in the sestamibi scan negative patients ${ }^{14,15}$. Therefore, we performed washout examination routinely. Further we used gama probe routinely instead of frozen section pathology examination. The localization of the adenoma was determined with the help of peroperative gamma probe. In this method, Tc-99 m MIBI was given intravenously to the patient preoperatively and surgery was started 30 minutes later.

The success rate of detection and removal of adenoma was found to be high with MIP (minimal invazive parathyroidectomy) using gamma probe. In addition, the radioactive material given for gamma probe was considered to be within the safe range when the level of absorbance in normal tissues was evaluated; compared to many other radiological examinations, it is considered to be at very low levels ${ }^{16}$.

In a study of 3388 patients with primary hyperparathyroidism, 964 (28\%) patients underwent parathyroidectomy. It has been reported that comorbid causes are not statistically significant in the discontinuation of surgical treatment, and that withdrawal from surgery is not beneficial in the evaluation of life expectancy in elderly patients with primary hyperparathyroidism ${ }^{17}$. In some studies, only $10-20 \%$ of all patients with PHP undergo surgery ${ }^{18,19}$. In our study group, the rate of geriatric patients was $40 \%$. In contrast to the general population of our country, this ratio was accepted as normal due to the fact that we are in a region where the elderly population is higher. Young patients with PHP have significantly higher serum calcium levels than older patients. However, young patients are less likely to localize abnormal parathyroid glands on $90 \mathrm{mTc}$ MIBI scintigraphy or ultrasound. Although younger patients have a higher rate of hyperplasia than elderly patients, adenoma is still the most common cause ${ }^{20}$. In our study, preoperative calcium and phosphorus values were significantly different in group 1. Although early postoperative calcium values differed, no difference was detected in both groups at first month control.

There is no globally accepted approach for PHP. Clinicians evaluate and determine their medical approaches in terms of cost, experience and suitability. In the United Kingdom, 90\% of surgeons performed 
preoperative USG and $90 \mathrm{mTc}-\mathrm{MIBI}$ scintigraphy; $30 \%$ had SPECT examination; it has been reported. $31 \%$ of surgeons performed frozen section and only $41 \%$ of surgeons performed intraoperative $\mathrm{PTH}$ (IOPTH) evaluation ${ }^{21}$.

It has been reported that intraoperative quick PTH follow-up increases the success rate in minimally invasive parathyroidectomy with intraoperative PTH (IOPTH) focusing and may be peroperative supportive in the detection of double adenomas ${ }^{14}$. However, IOPTH measurements were not performed in our clinic. Because we routinely used preoperative washout examination, USG and 90 mTc-MIBI scintigraphy scans. In addition to this gama probe verification of suspected adenomas were used. Our success rate is higher as is the literature. Thus, we did not need to use IOPTH. Besides, we also corralate our results with 10th minute and 24th hour measurements. We claim that routine quick IOPTH may not be used in PHP surgery routinely.

If the blood PTH level decreases by $50 \%$ after the operation, it is decided that the adenoma is removed successfully ${ }^{8,16}$. In our study, parathormone levels decreased significantly in the early postoperative period compared to the preoperative levels, especially in the group $\geq 65$ years, statistically significantly lower than the other group PTH levels in both early postoperative and postoperative 1 st month.

Since the beginning of the 21 st century, minimally invasive techniques have been developed for unilateral exploration $^{21}$. With minimally invasive surgery, more successful cosmetic results, lower pain, lower hospital stay were determined ${ }^{5}$. We performed minimally invasive surgery for all patients. In our study, the duration of discharge time from the hospital was found to be close in both groups without any statistical difference.

It was reported that the complication rate of conventional parathyroidectomy (3\%) was higher than that of minimally invasive parathyroidectomy (1.2\%) and the rate of unilateral nerve injury was close in both methods ${ }^{22}$.

Although minimally invasive parathyroidectomy has lower complication rates, shortened hospital stay, and a significant reduction in hospital bills. However, a study reported that only $3 \%$ of United Kingdom (UK) surgeons performed minimally invasive parathyroidectomy ${ }^{23}$. We did not encountered with nerve injury or permanent hypocalcemia both in geriatric and adult groups. Our mean discharge time from hospital is very low. To perform minimally invasive parathyroidectomy the surgery team should be experienced. Otherwise like in UK surgeons the rate of this surgery would be lower than $5 \%$.

There are some studies reporting that; advanced surgical techniques even in geriatric patients could be safely preferable via outpatient clinic under local anesthe$\operatorname{sia}^{24}$. Although our patients are older we did not use local anestesia surgery.

Limitations of our study are having a low volume of patient groups, lack of routine using of quick PTH assays and to be planned as a retrospective study.

As a result, minimally invasive parathyroid surgery can be safeley performed in geriatric patients. In addition, to avoid from the complications of hypercalcemia due to delayed surgery, can be preventable by minimallay invasive parathyroid surgery. Exact localisation of adenoma can detected preoperatively with multidisiplinary approach including washout examination, USG and 90 mTc-MIBI scintigraphy scans even witout IOPTH mesaurments. Furthermore, to reveal certain results, we need high volume prospevtive studies for minimally invasive parathyroid surrgery. Our study is the first in our literature about minimal invasive parathyroid surgeryon geriatric patients.

\section{References}

1. Deiner S, Westlake B, Dutton RP. Patterns of Surgical Care and Complications in the Elderly. J Am Geriatr Soc. 2014;62(5):82935 .

2. Modawal A, Ansari S, Fazili S. Management of Geriatric endocrine disorders. Compr. Ther. 2004;30:10-17.

3. Nilsson IL. Primary hyperparathyroidism: should surgery be performed on all patients? Current evidence and residual uncertainties. Journal of Internal Medicine 2019;285:149-64.

4. Boonen S, Vanderschueren D, Pelemans W, Bouillon R. Primary hyperparathyroidism: diagnosis and managment in the older individual. European Journal of Endocrinology 2004;151:297304.

5. Butt HZ, Husainy MA, Bolia A, London NJM. Ultrasonography alone can reliably locate parathyroid tumours and facilitates minimally invasive parathyroidectomy. Ann R Coll Surg Engl 2015;97:420-24.

6. Clark OH. Diagnosis of Primary Hyperparathyroidism. In: Textbook of Endocrine Surgery Ed: WB Saunders Comp., Philadelphia; 1997:297-300, 358-359.

7. Hopkins CR, Reading CC. Thyroid and parathyroid imaging. Semin Ultrasound CT MR 1995;16:279-95. 
8. Koroğlu R, Koroğlu M. Parathyroid scintigraphy in preoperative detection of parathyroid adenomas and use of gama probe in minimal invasive surgery. Clin Exp Invest 2011;2(2):238-43.

9. Sarıcı B, Soyer V, Unal B, Koc S, Onur A, Dirican A. Intrathymic Parathyroid Adenoma Causing Persistent Hyperparathyroidism : Case Report. Causa Pedia 2015;4:1073.

10. Stechman MJ, Weisters M, Gleeson FV, Sadler GP, Mihai R. Parathyroidectomy is safe and improves symptoms in elderly patients with primary hyperparathyroidism (PHPT). Clinical Endocrinology 2009;71:787-99.

11. Tibblin S, Palsson N, Rydberg J. Hyperparathyroidism in the elderly. Ann Surg 1983;197(2):135-138.

12. Inversini D, Morlacchi A, Melita G, Del Ferraro S, Boeri C, Portinari M, et al. Thyroidectomy in elderly patients aged $\geq 70$ years. Gland Surg. 2017;6(5):587-90.

13. Ben Haim M, Zwas ST, Munz Y, Rosin D, Shabtai EL, Kuriansky J, et al. Focused, minimally invasive radio-guided parathyroidectomy: a feasible and safe option for elderly patients with primary hyperparathyroidism. Isar Med Assoc J 2003;5(5):326-8.

14. Pradhan R, Guota S, Agarwal A. Focused Parathyroidectomy Using Accurate Preoperative Imaging and Intraoperative PTH: Tertiary Care Experience. Indian J. Endocrinol Metab. 2019;23(3):347-52.

15. Pekkolay Z, Tuzcu S. Importance of parathyroid hormone needle aspiration washout in adenoma localization in primary hyperparathyroidism. Med Sci Monit 2019:1694-8.

16. Urkan M, Peker YS, Ozturk E. Minimally invasive parathyroidectomy for primary hyperparathyroidism Acta Endocrinologica (Buc) 2019;15(2):82-86.
17. Wu B, Haigh PI, Hwang R, Ituarte PHG, Liu ILA, Hahn TJ, et al. Underutilization of Parathyroidectomy in Elderly Patients with Primary Hyperparathyroidism. J Clin Endocrinol Metab. 2010;95(9):4324-30.

18. Ljunghall S, Hellman P, Rastad J, Akerstro MG. Primary hyperparathyroidism: epidemiology, diagnosis and clinical picture. World J Surg 1991;15:681-7.

19. Wermers RA, Khosla S, Atkinson EJ, Achenbach SJ, Oberg AL, Grant CS, et al. Incidence of primary hyperpara- thyroidism in Rochester, Minnesota, 1993-2001: an update on the changing epidemiology of the disease. J Bone Miner Res 2006;21:171-7.

20. Kandil E, Majid DS, Carson KA, Tufano RP. A Comparison of Outcomes for Younger and Older Adult Patients Undergoing Surgery for Primary Hyperparathyroidism. Annals of Surgical Oncology. 2012;19(6):1897-1901.

21. Korwar V, Yuen Chang F, Teasdale E, Suchett-Kaye I, Edwards A, Morgan J. Stepwise Approach for Parathyroid Localisation in Primary Hyperparathyroidism. World J Surg. 2019;11. doi: 10.1007/s00268-019-05269-4.

22. Wong W, Foo FJ, Lau MI, Sarin A. Kiruparan P. Simplified minimally invasive parathyroidectomy: a series of 100 cases and review of the literature. R Coll Surg Engl 2011;93:290-3.

23. Ozbas S, Pain S, Tang T, Wishart GC. Surgical management of primary hyperparathyroidism - results of a national survey. Ann R Coll Surg Engl 2003;85:236-41.

24. Fui SL, Bonnichon P, Bonni N, Delbot T, Andre JP, PionGraff J,et al. Hyperparathyroidism in octogenarians: A plea for ambulatory minimally invasive surgery under local anesthesia. Ann Endocrinol (Paris) 2016;77(5):600-5. 